RARIES SMITHSONIAN INSTITUTION NOIINIIISNI NHINOSHIIWS S I Y

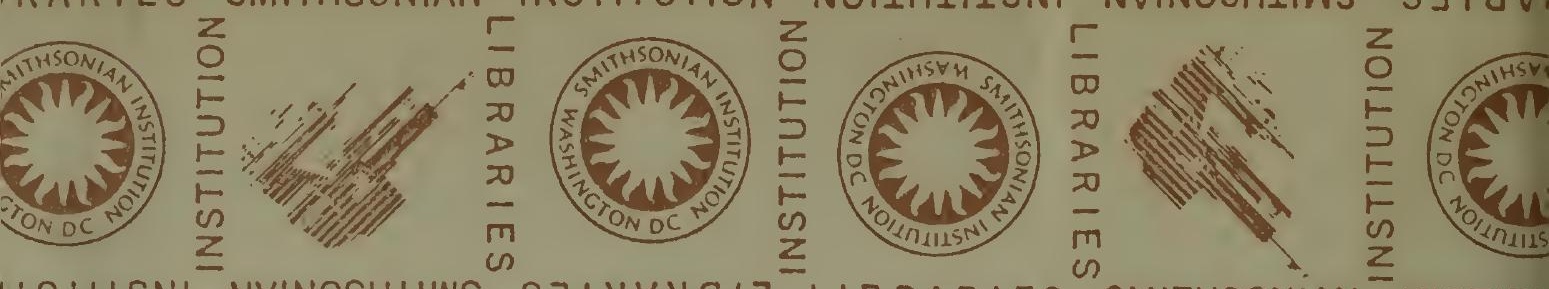

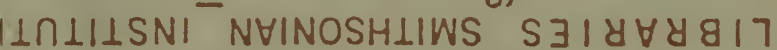

IBRARIES SMITHSONIAN INSTITL
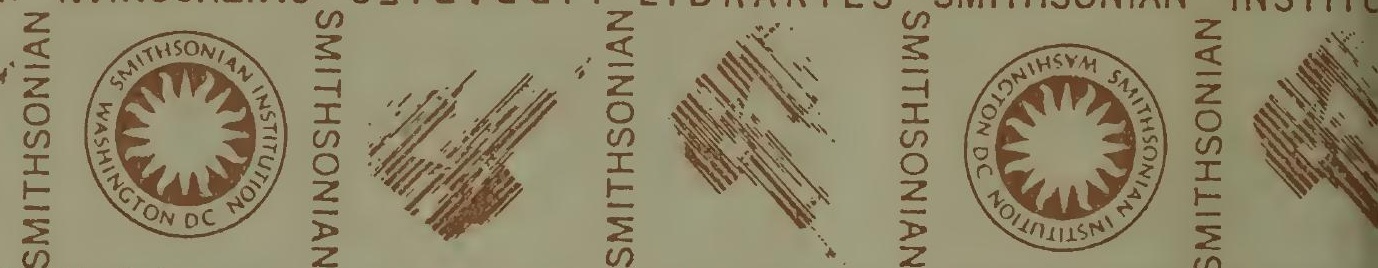

RRARIES SMITHSONIAN
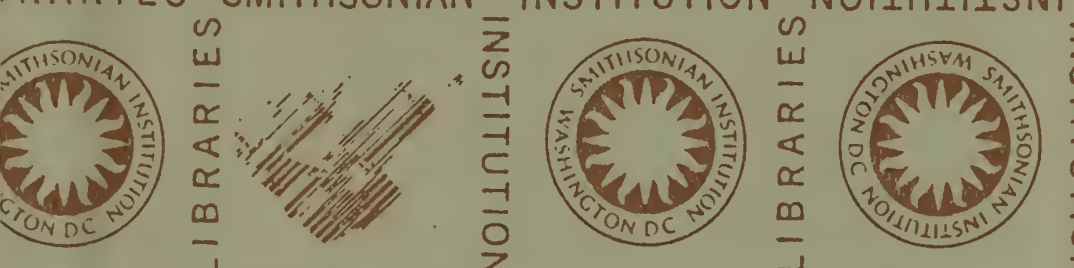

$\perp \cap \perp \perp S N I^{-}$NHINOSHLIWS
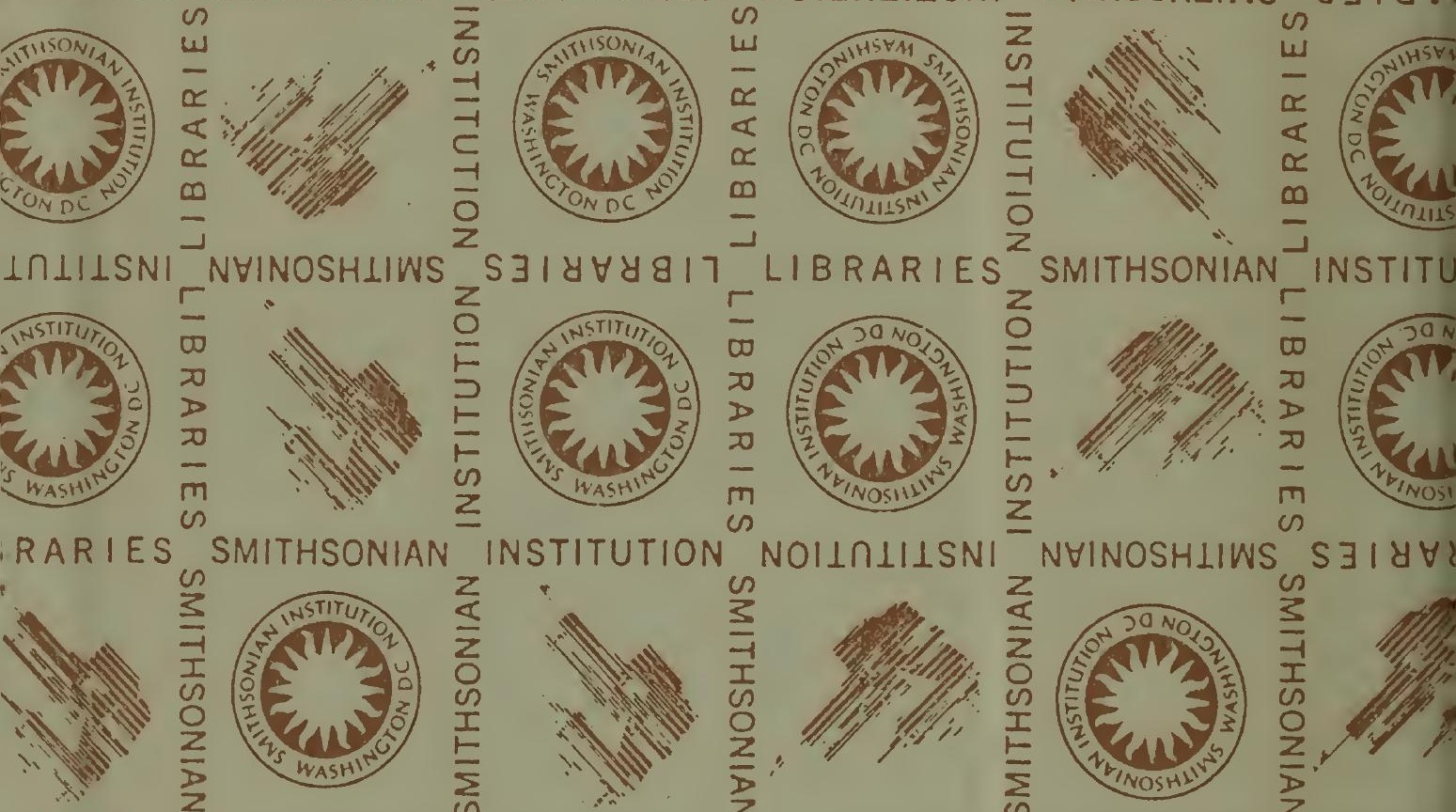

INSTITUTION NOIINIILSNI
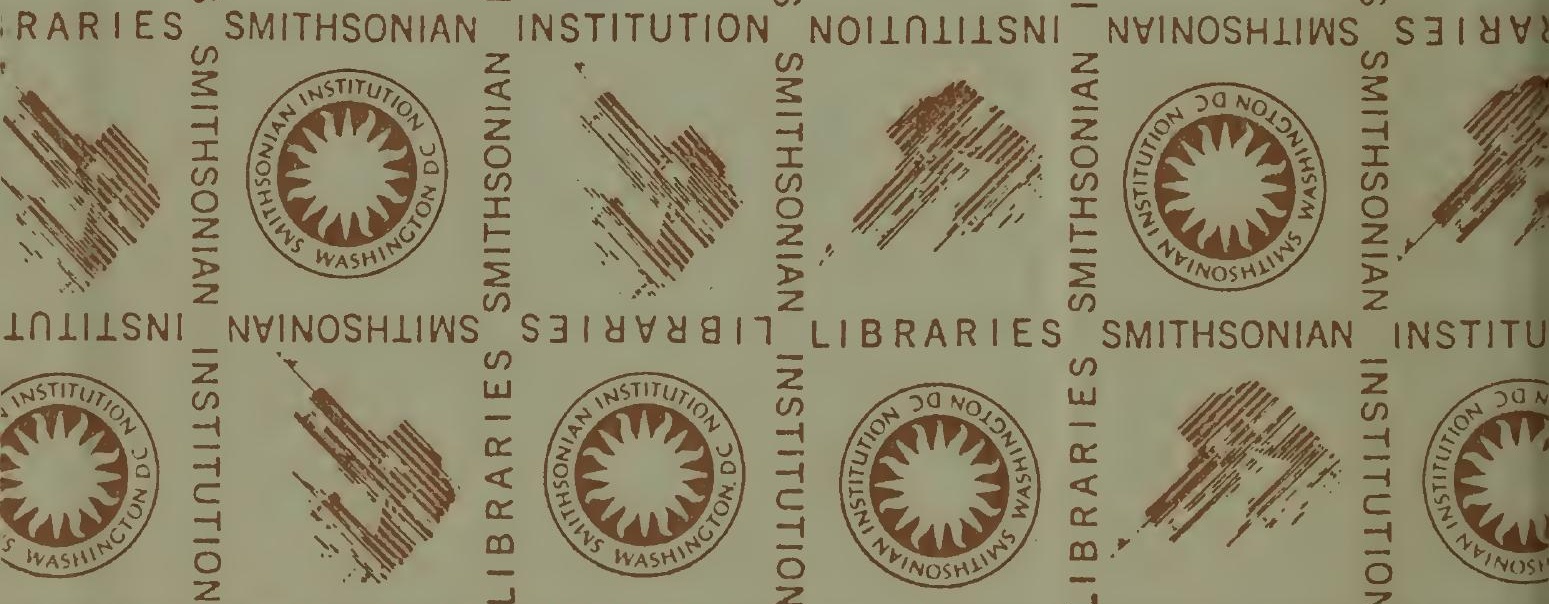

RARIES SMITHSONIAN
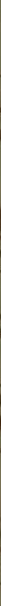

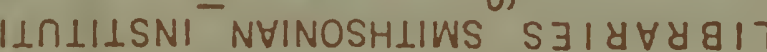
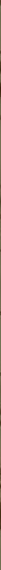

INSTITL

BRARIES SMITHSONIAN
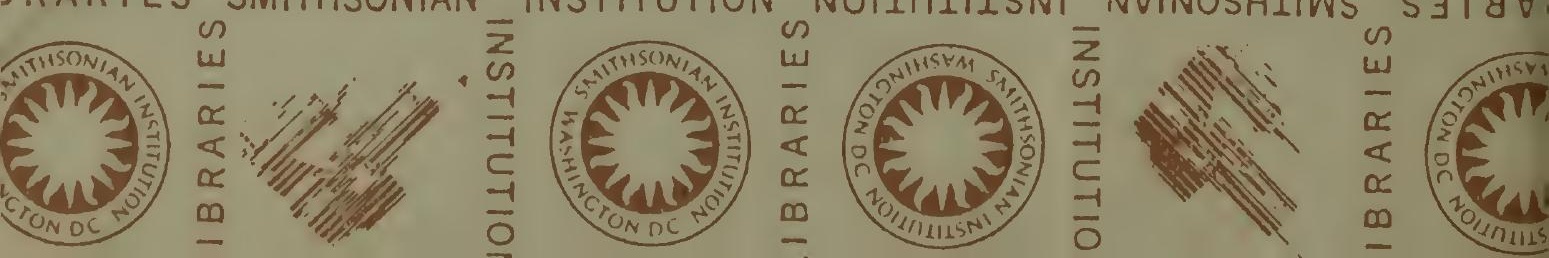


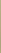
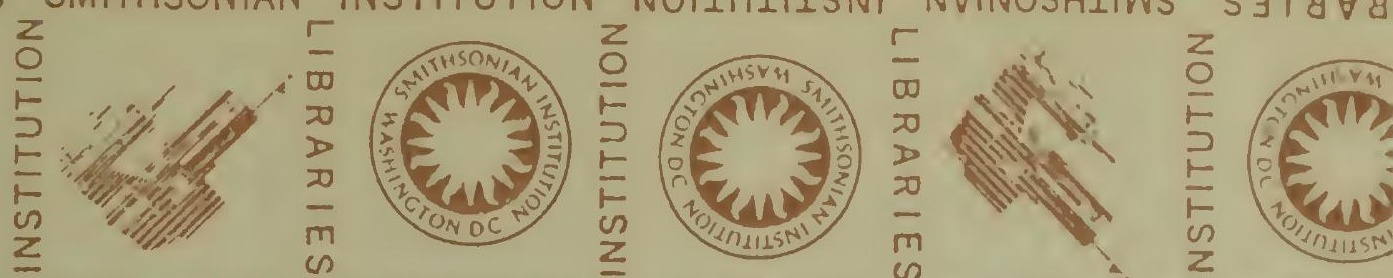

กIILSNI NVINOSHLIWS

S 31 प $\forall 4817$

LIBRARIES SMITHSONIAN

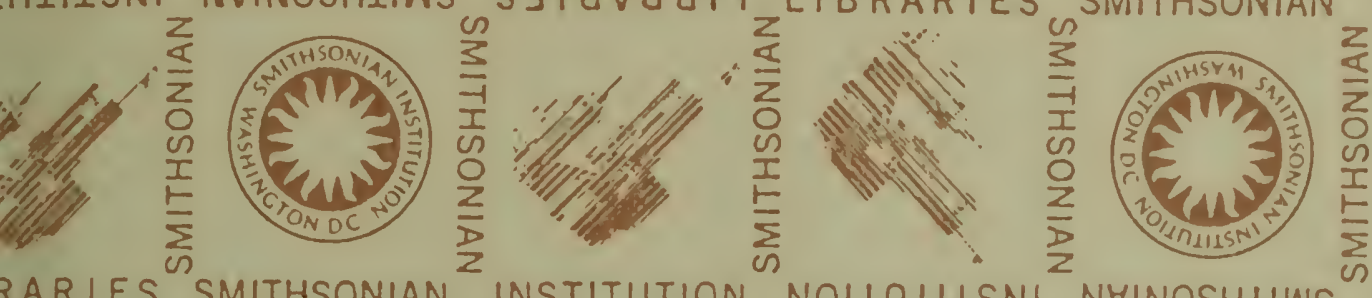

INSTITUT

INSTITUTION
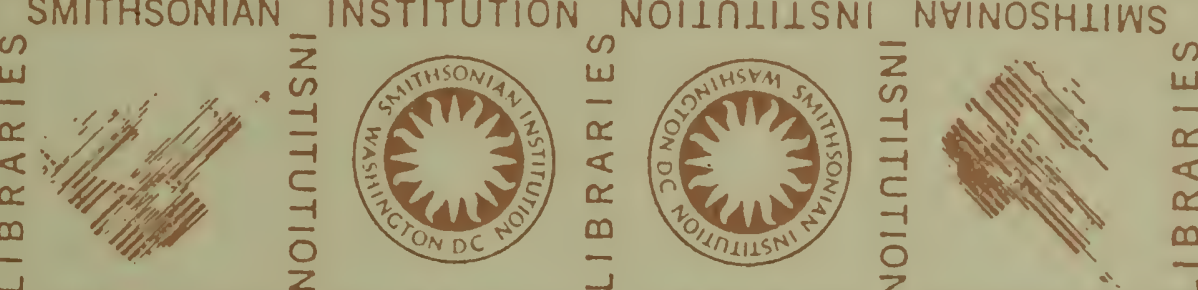

$S \exists I \forall \forall \forall$ กLILSNI NHINOSHLIWS S $\exists I$ YYY817 LIBRARIES

SMITHSONIAN INSTITUT
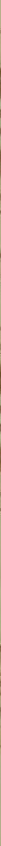

INSTITUTION NOIINIIISNI
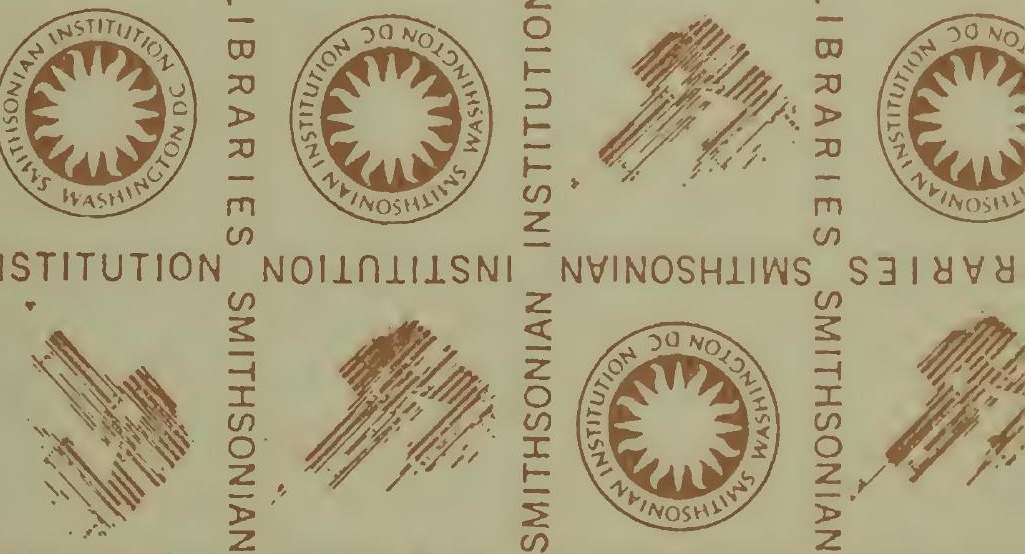

$S \exists I \forall \forall y$ OIILSN
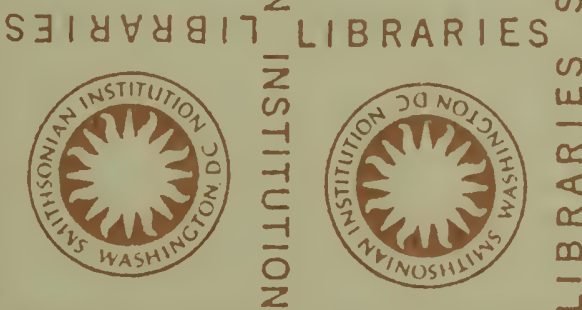

SMITHSONIAN
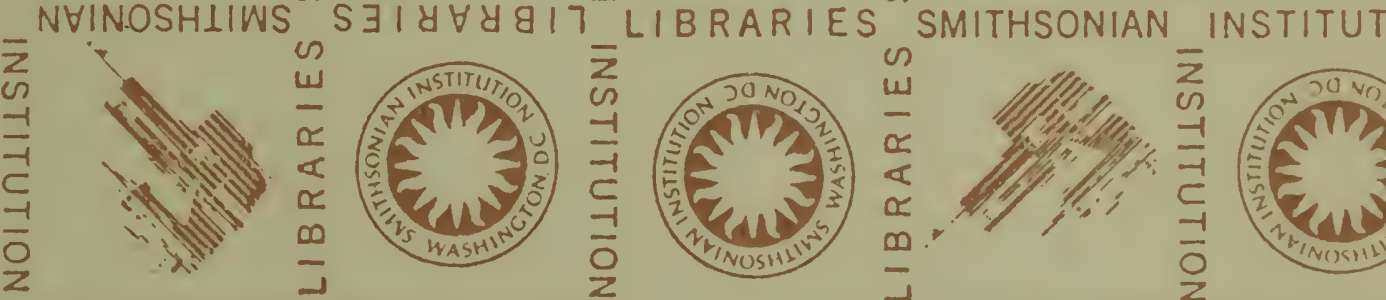

SMITHSONIAN
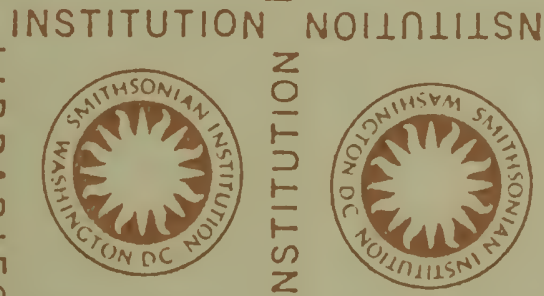

NVINOSHLIWS

$S \exists 1 y \forall y$
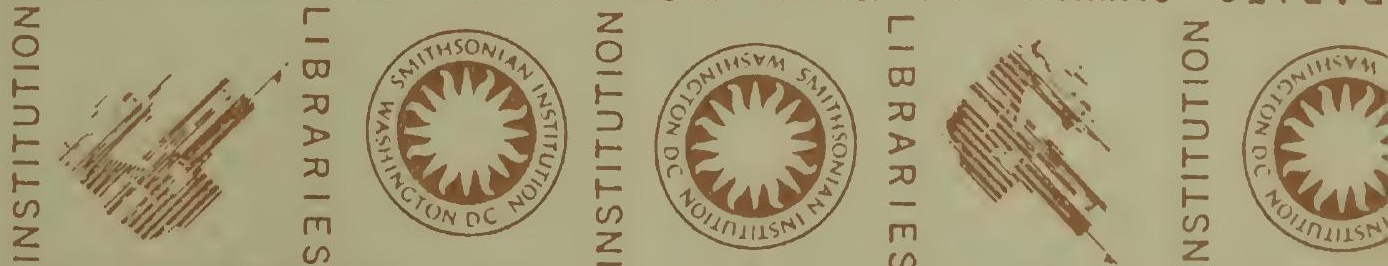

IIISNI
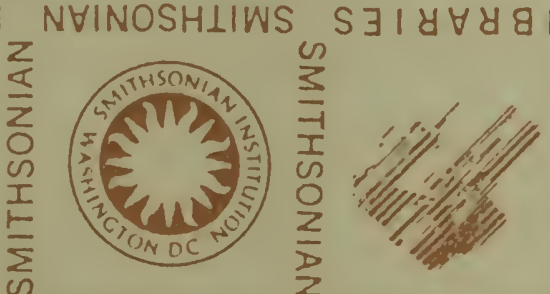

$z$
$z$
$\vdots$
0
0
I
$\sum_{i=0}$
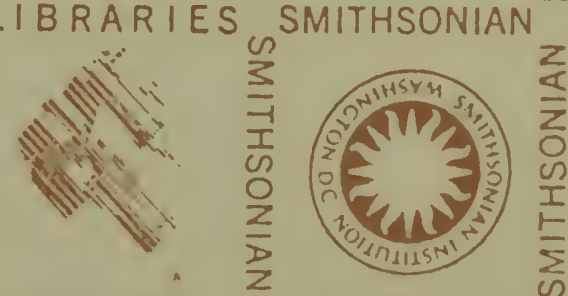

INSTITUT

RARIES SMITHSONIAN INSTITUTION NOIINIIISNI
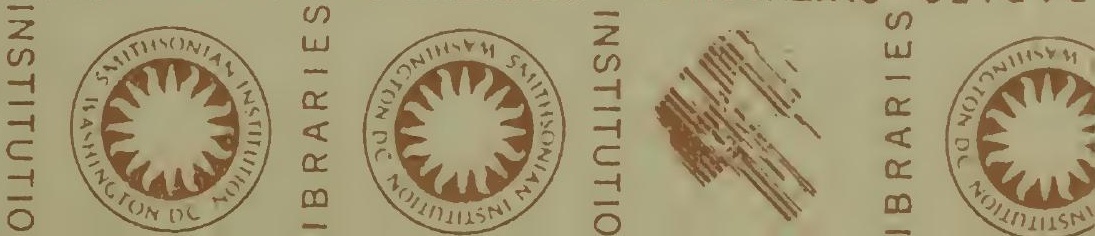



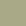



MATHER BROWN'S

\section{PORTRAIT OF JOHN ADAMS}

BYY

LAIVRENCE PARK

From the

Proceedings of the Massachusetts Historical Society FOR NOVEMBER, I9I7

BOSTON

THE UNIVERSITY PRESS

I 9 I 8 


$$
\text { ov }
$$





$$
\text { . }
$$




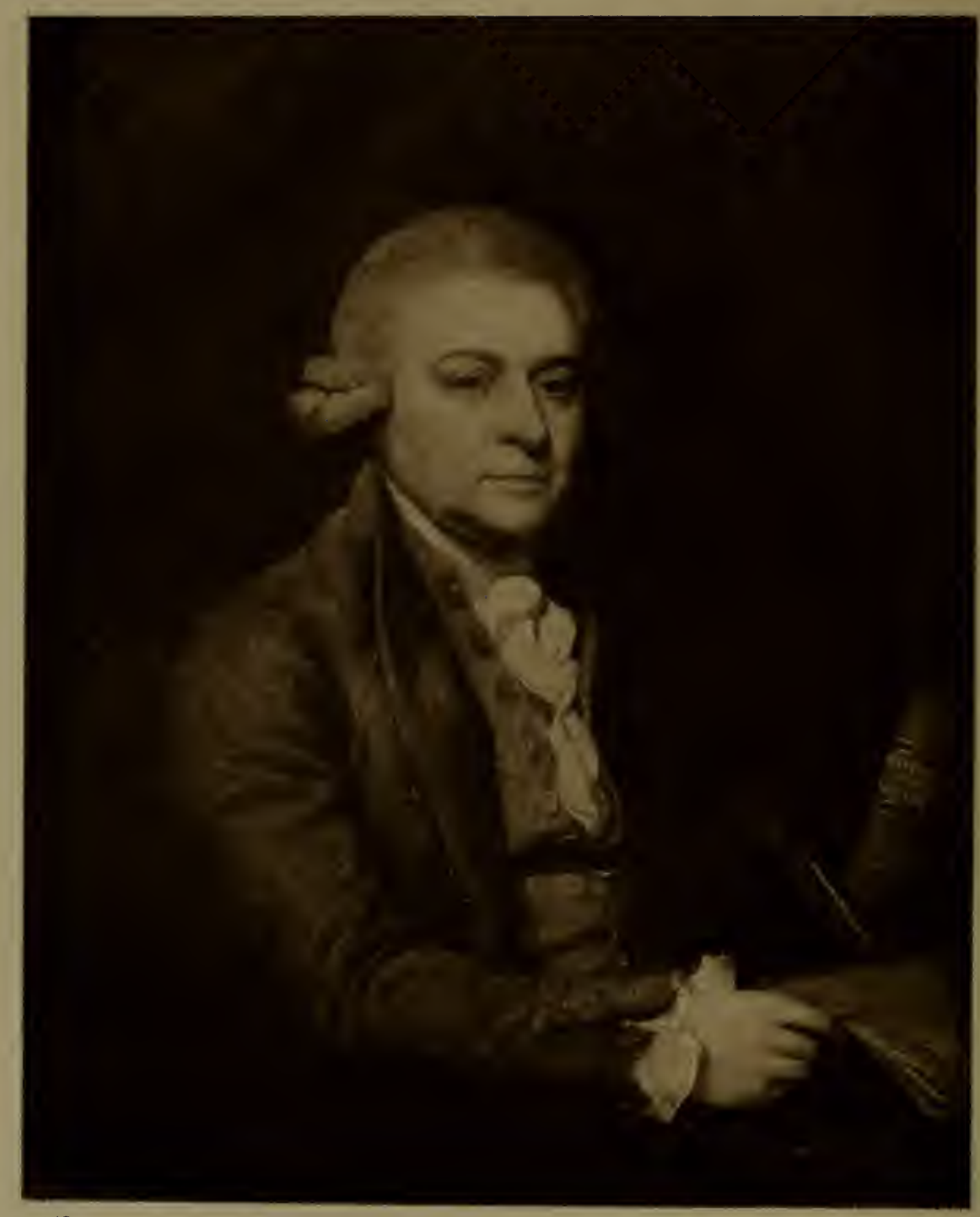

MHS

$$
\begin{aligned}
& \text { Gotere. Alderines }
\end{aligned}
$$

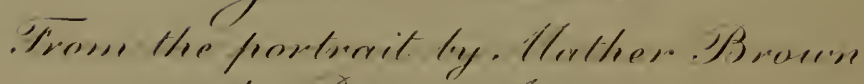

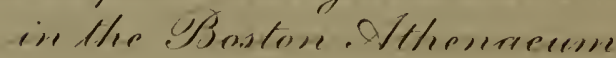




\section{MATHER BROWN'S PORTRAIT OF JOHN ADAMS}

In 1786, Mather Brown, then twenty-five years old, painted a portrait of Thomas Jefferson, who had come to London to visit John Adams. In Jefferson's accounts he entered on April 25, I 786, "Pd. Brown for my picture, £ıo." At about the same time he painted a replica of this portrait for John Adams, which is now in the possession of the Adams family, and for which he charged six guineas, as is shown by his receipt attached to the back of the picture. The original portrait seems to have disappeared. Jefferson gave an order to Brown for a portrait of John Adams, and the receipt for its cost, $£_{\text {Io, }}$ dated July 2, I 788, is reproduced in Proceedings, xLvII. 33. Trumbull writing from London to Jefferson in Paris in $\mathrm{I} 788$, and referring to the two portraits says: "Mr. Adams is like - yours I do not think so well of." The Adams portrait of Jefferson was engraved for Bancroft's History of the United States, and has been several times reproduced. It is the earliest-known likeness of him.

The portrait of Adams I think has never been engraved or hitherto reproduced in any book. It remained in Jefferson's possession until his death in 1826 and in May, I828, was, with many paintings from his estate, exhibited at the Boston Athenxum, numbered 3 II in the catalogue and offered for sale. It next appears at an auction of Jefferson's pictures held in Chester Harding's Gallery on School Street, Boston, July 19, I833. Since that date it has been lost sight of. The picture itself is owned by the Boston Athenæum and hangs in the delivery room of that building. It was received by bequest in 1908 from the late George Francis Parkman of Boston, who doubtless inherited it from his father or grandfather, who in turn probably 
purchased it from the Jefferson estate. During the past year I have made some study of the work of Brown, and having compared this portrait with others of Adams, I am now convinced that it is the long-lost portrait of Adams by Brown. The introduction in the right of the picture of a folio volume labelled "Jeffersons Hist. of Virginia." implies a delicate compliment to Jefferson.

Mather Brown had an earlier connection with John Adams. Writing in September, I784, to his aunts of his commissions, Brown states that he had painted "Miss Adams, Daughter of the famous Ambassador," who had touched in England while on her way from Quincy to Paris. A year later, September I3, I 785, he wrote that "among other great people" he had painted "the illustrious J. Adams, Esqr. (Ambassador from the States to His Britannic Majesty) and his Family, which will honour the next Exhibition." 1 The catalogues of the Royal Academy ${ }^{2}$ do not however show that these pictures were exhibited there. Miss Adams was Abigail Adams who married in 1786 . Her portrait and that of her husband, Col. William Stephens Smith, both by Brown, are owned in the Adams family. Another portrait of her, destroyed by fire many years ago, was engraved by H. S. Sadd for her Journal and Correspondence published in I84I. The engraving attributes the portrait to Copley, but I am not able, lacking further evidence, to state that it is not correctly attributed and that Brown and not Copley was the artist.

1 From Mather Brown letters in the Frederick L. Gay Transcripts.

2 Royal Academy Exhibitors, by Algernon Graves, 1. 310. 


. 




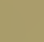






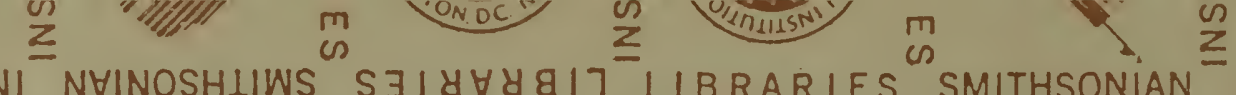

SSNI NHINOSHLIWS SJIY甘YG17 LIBRARIES SMITHSONIAN INSTITUTION
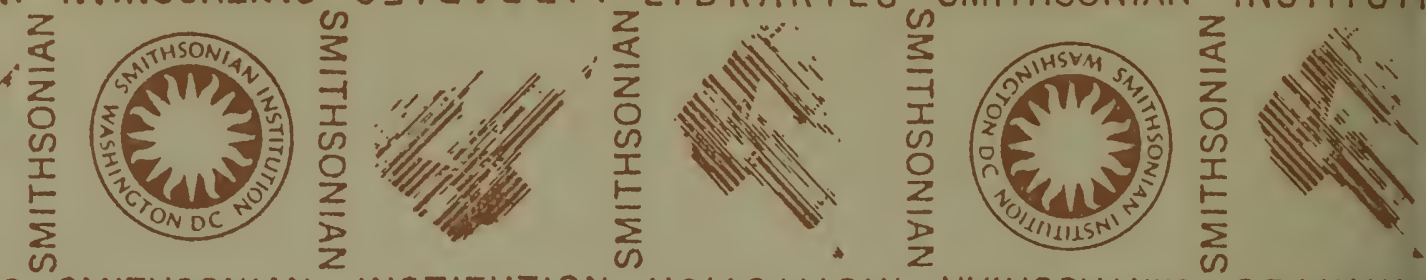

IES SMITHSONIAN
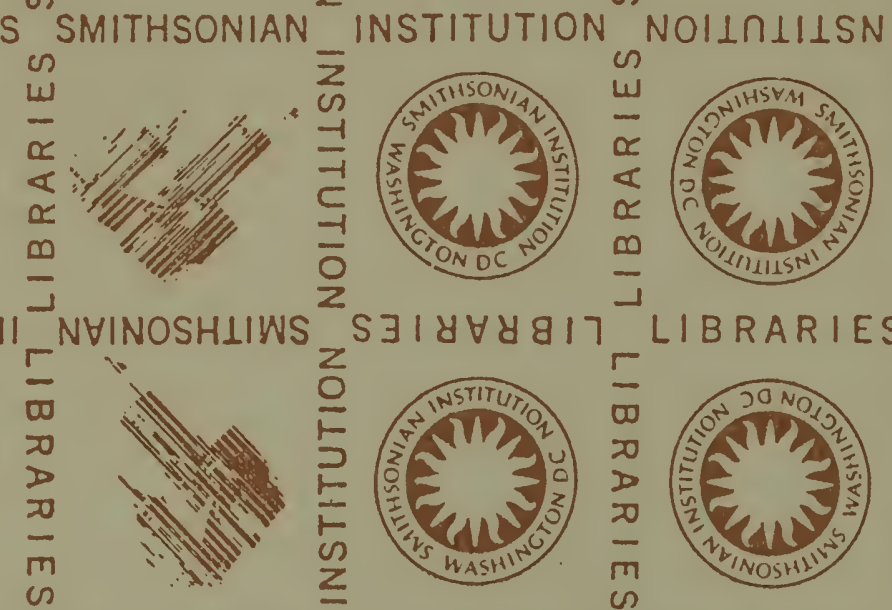

LIBRARIES
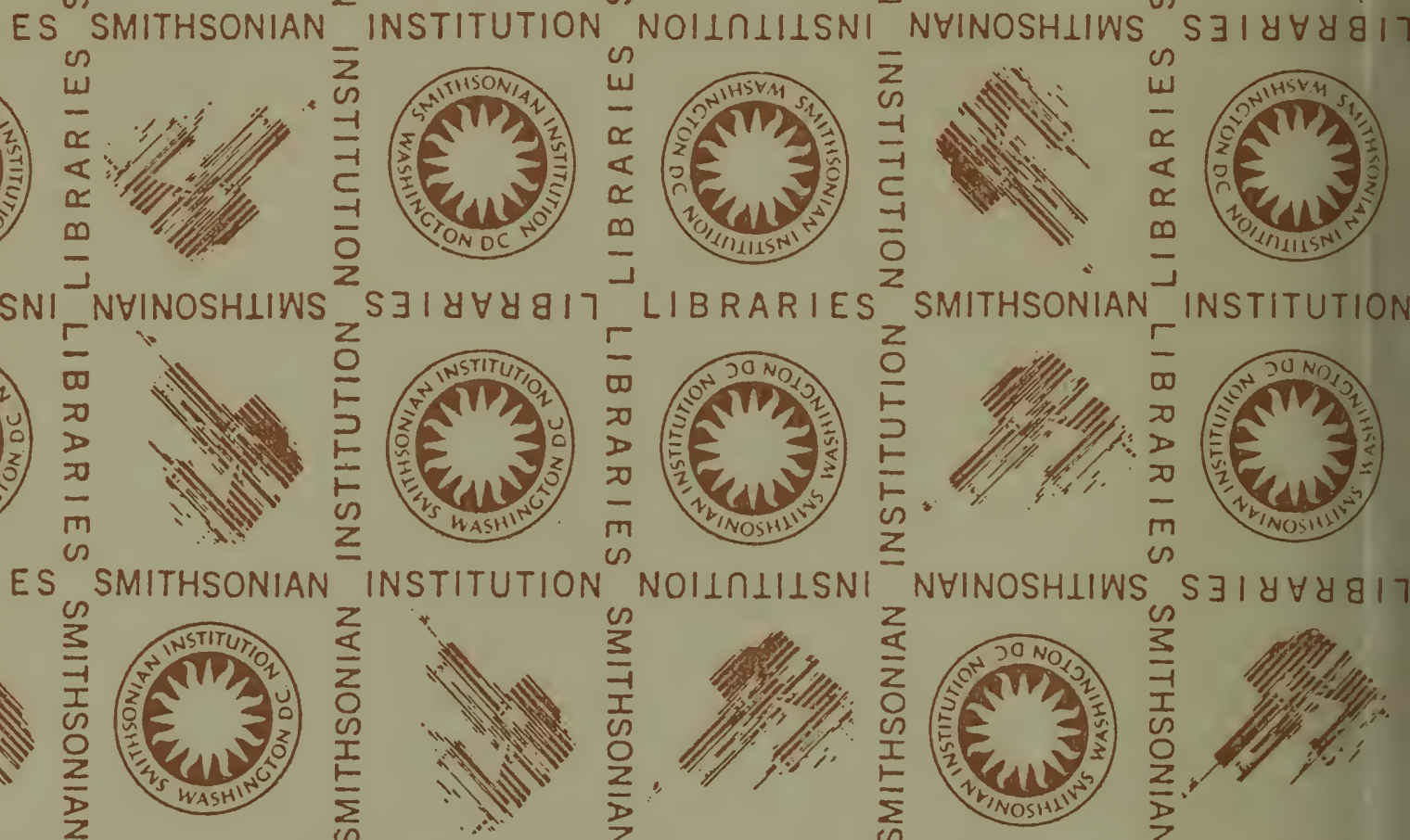

NOIINIIISNI

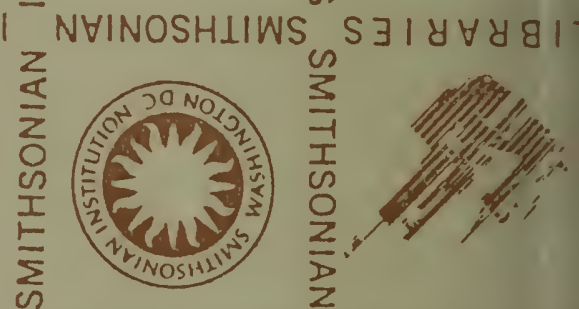

SNI
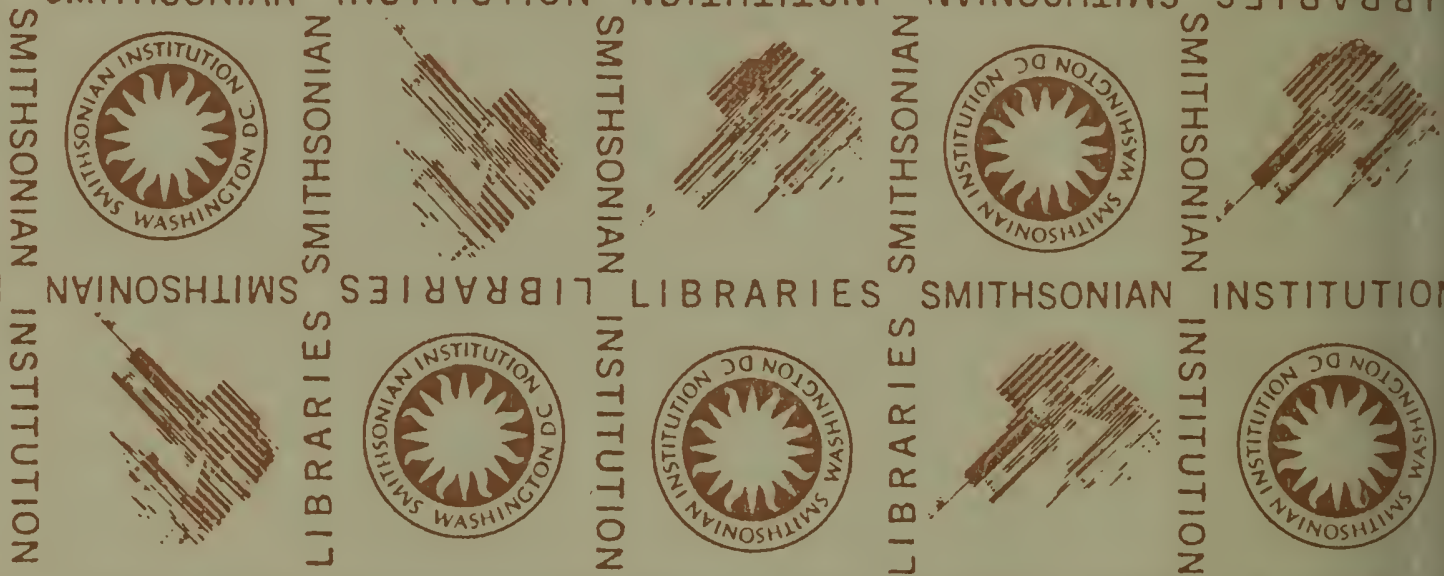

$\mid E$
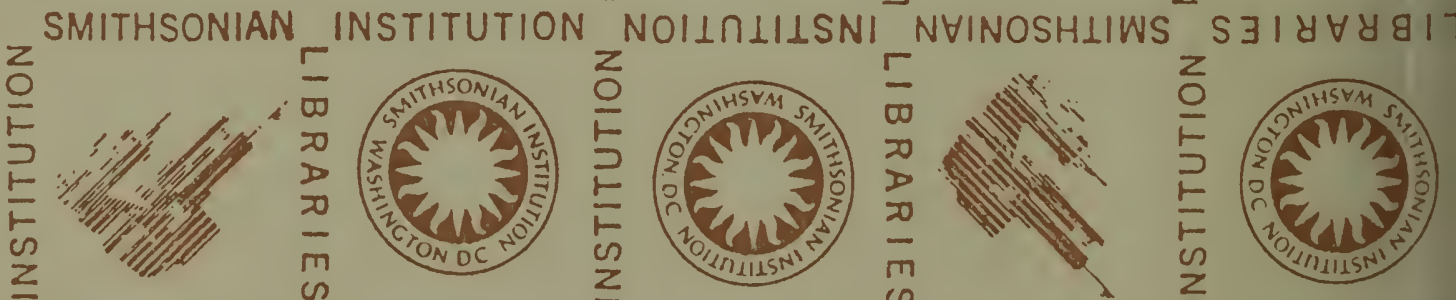

LSN
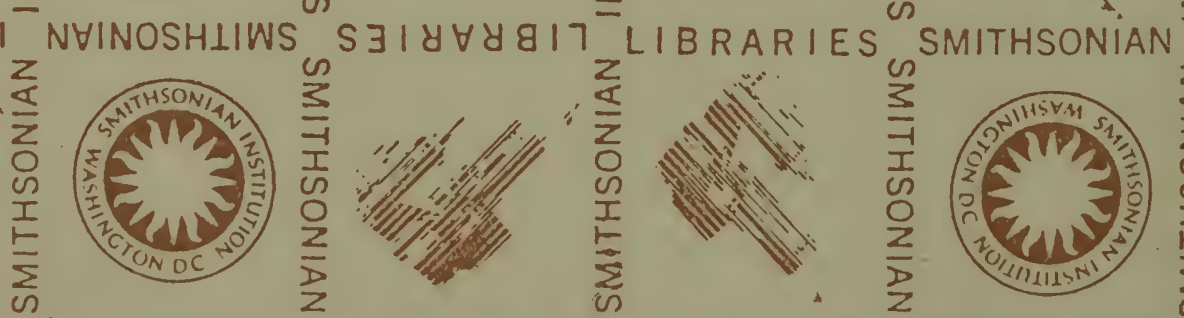

INSTITUTION
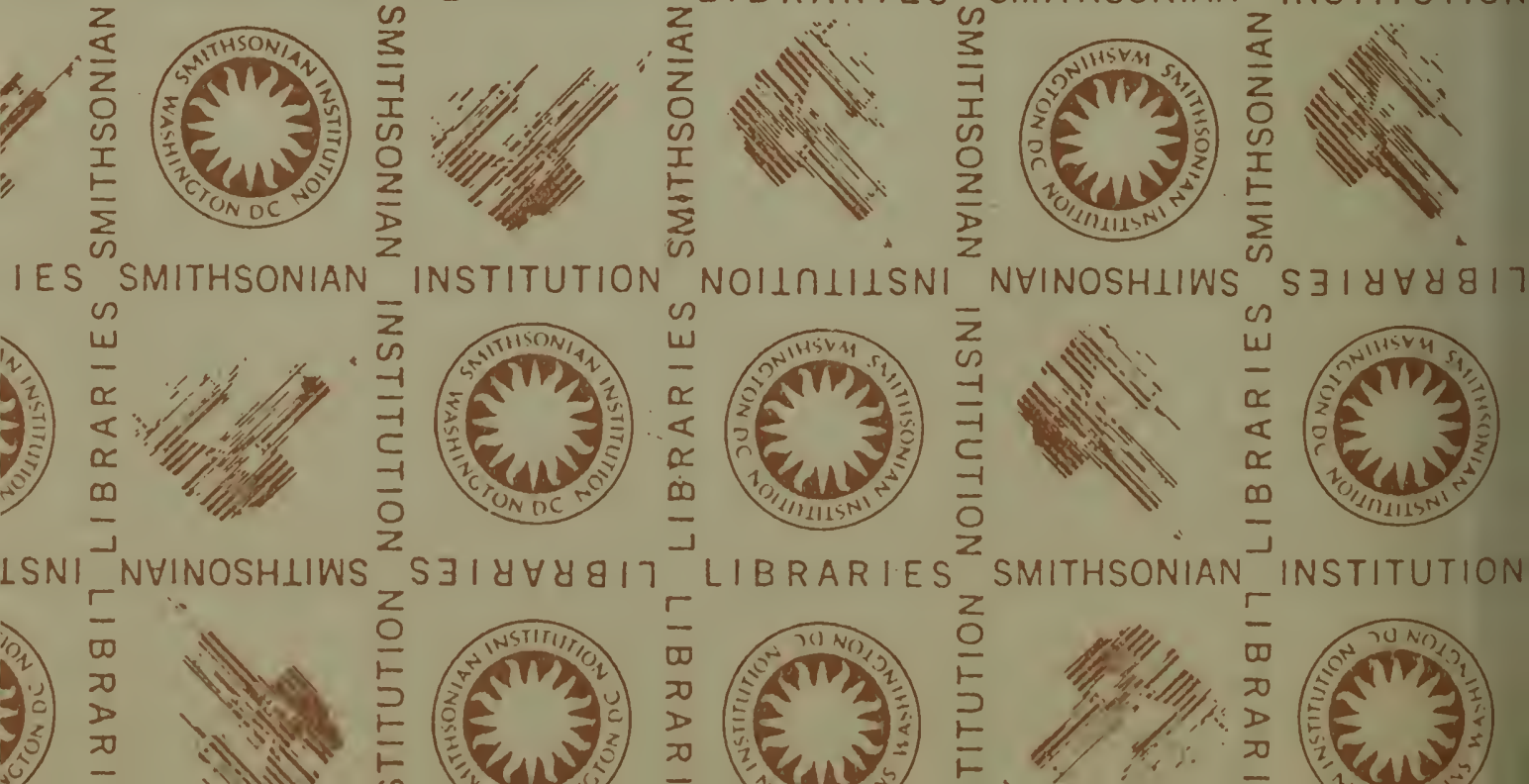


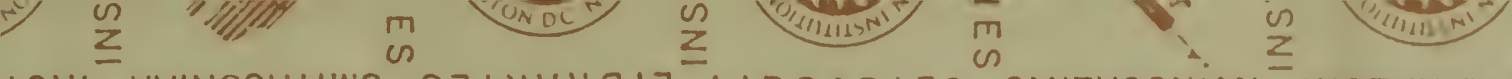

LSNI NHINOSHLIWS SJIY甘YGIT LIBRARIES SMITHSONIAN INSTITUTION
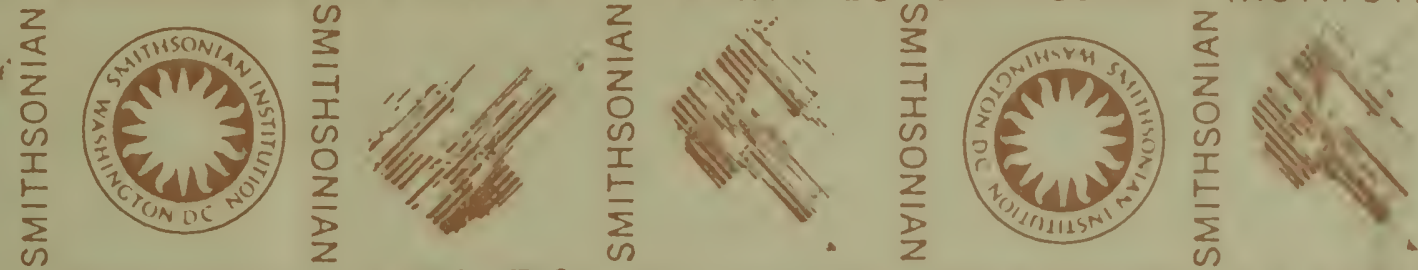

IES SMITHSONIAN

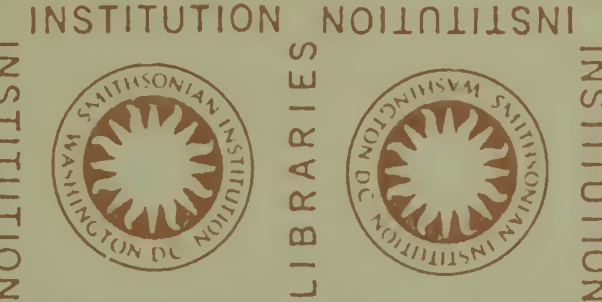

NVINOSHIIWS

S $\exists$ I 바이
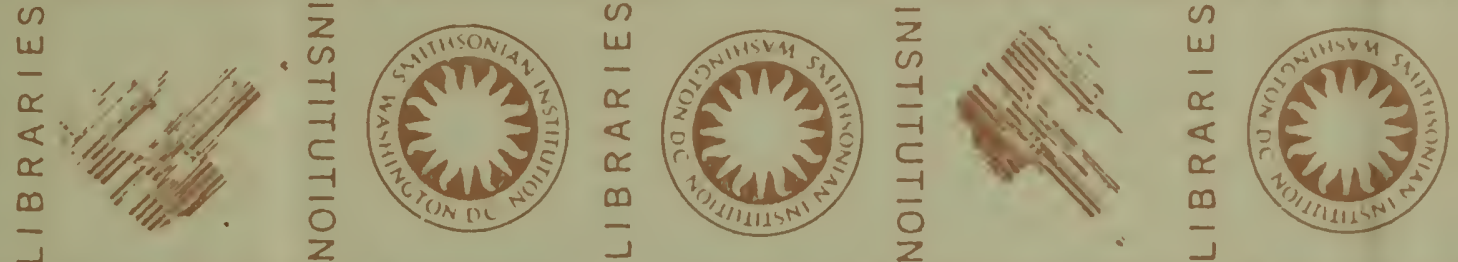

ISNI NHINOSHLIWS
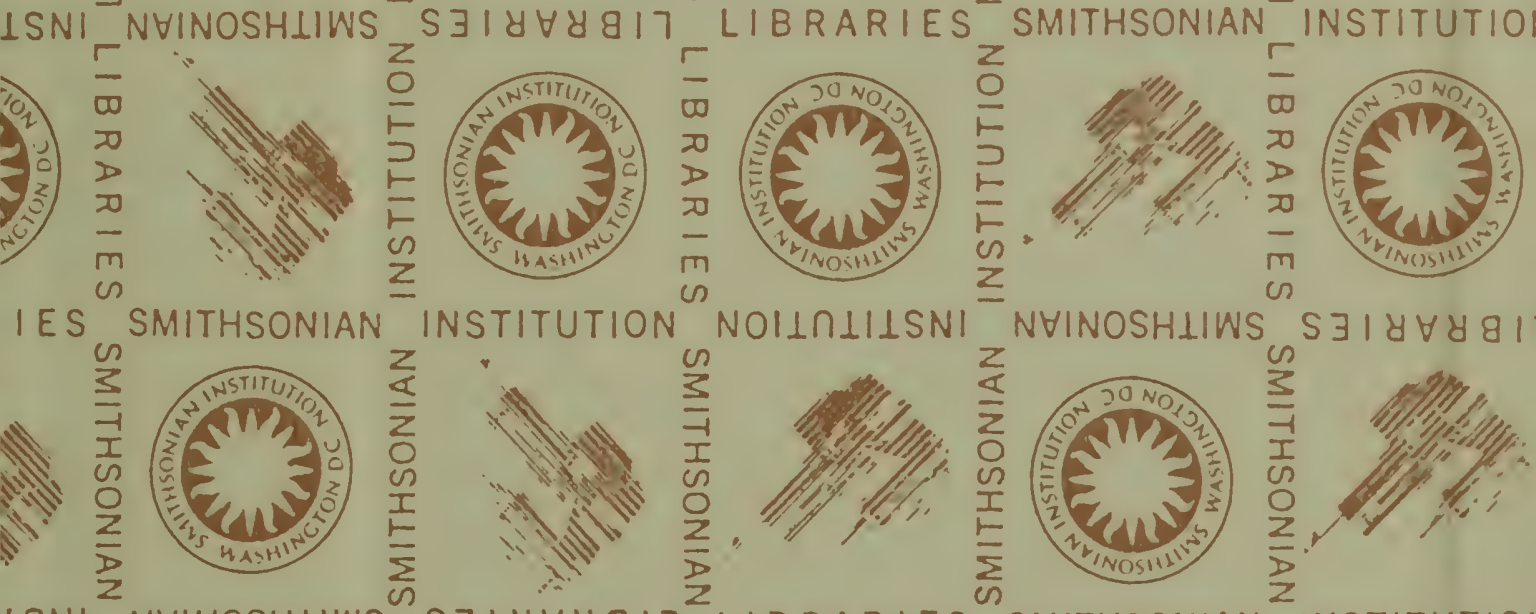

INSTITUTION
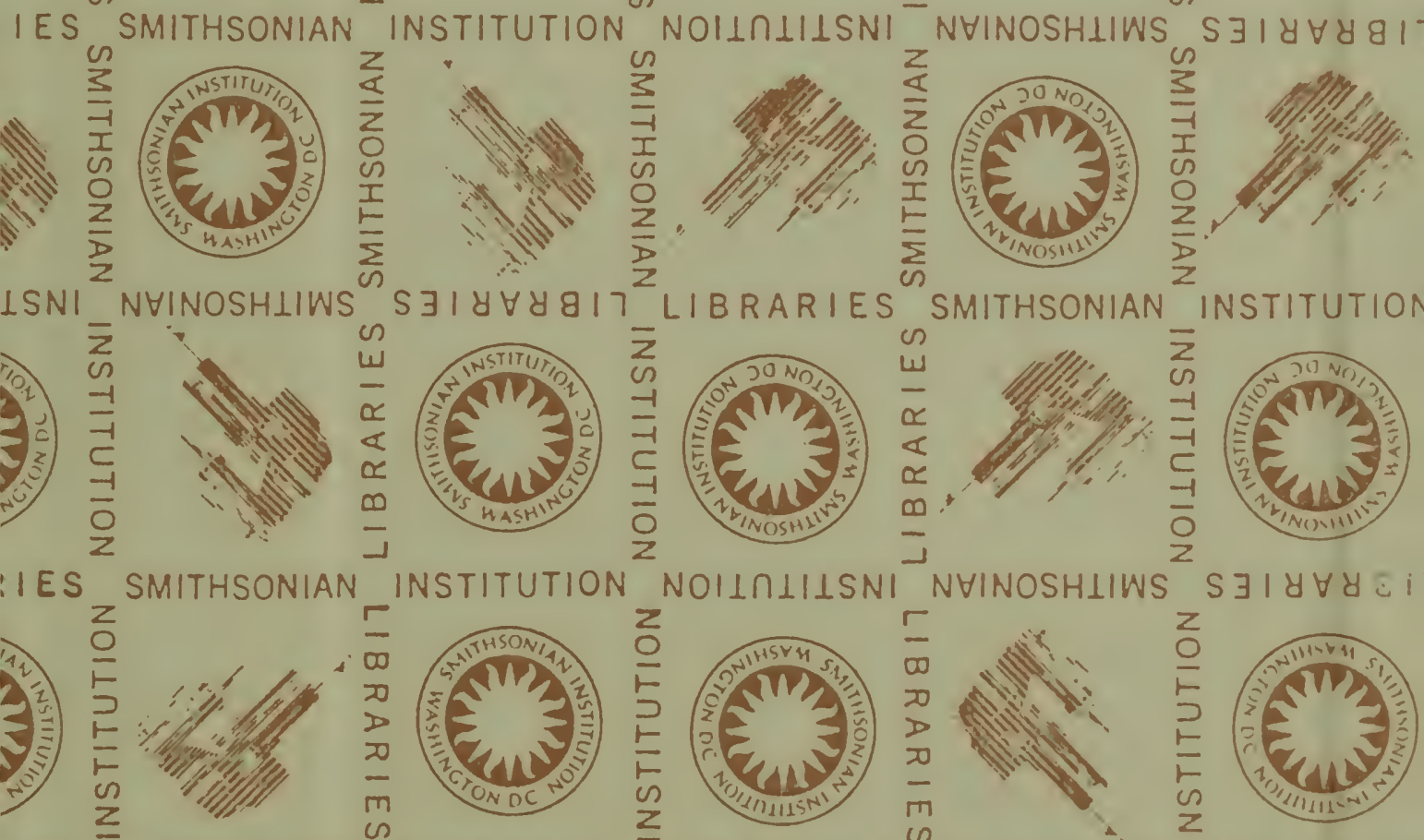

ISNI NVINOSHIIWS
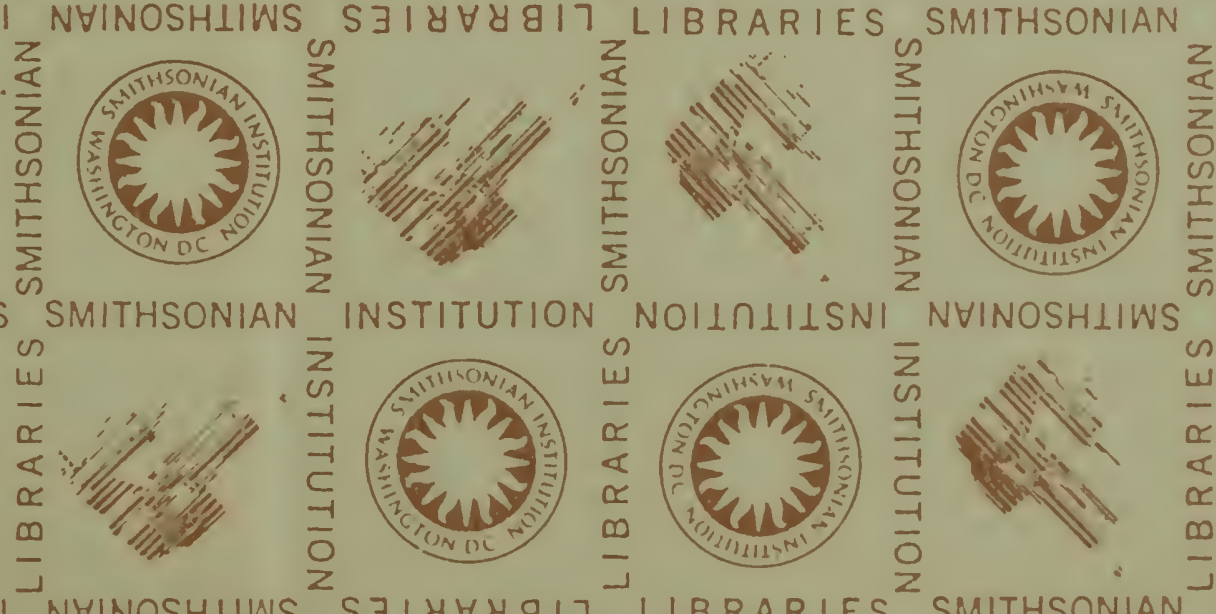

INSTITUTIOI
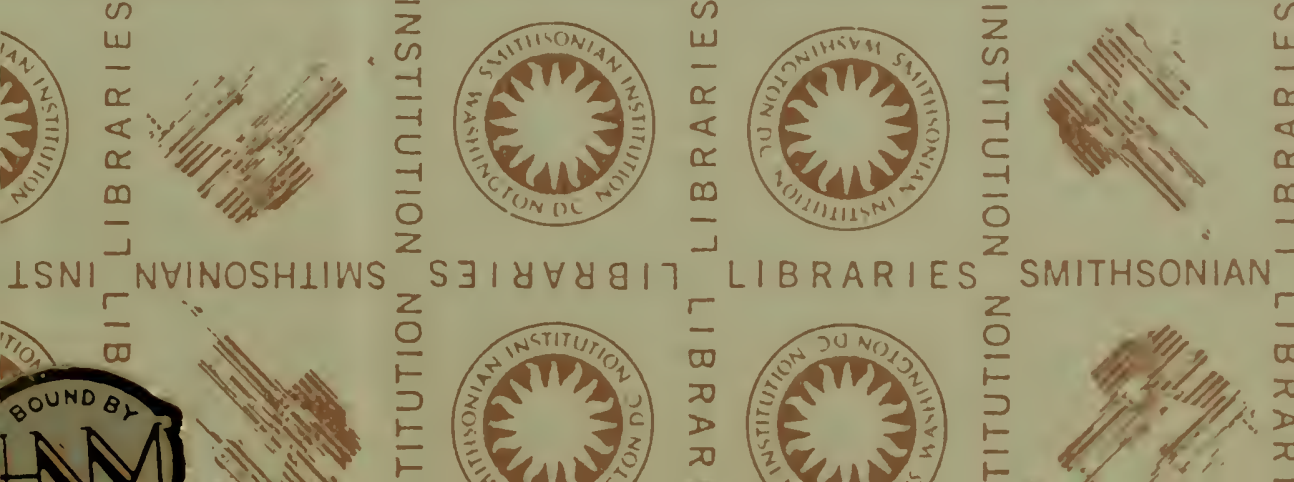

S $\exists \mid \forall \forall \forall 81$ LIBRARIES

SMITHSONIAN INSTITUTIOP

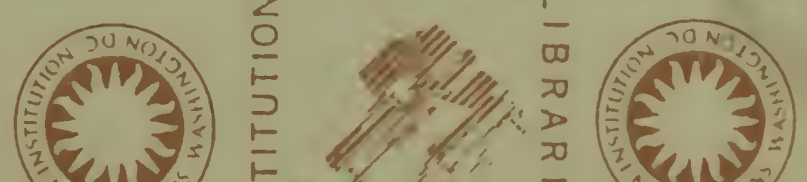


SMITHSONIAN INSTITUTION LIBRARIES

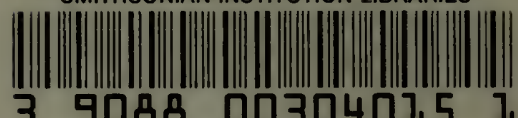

39088003040151

npg N40.1.B8785P2

Mather Brown's portrait of John Adams. 